\title{
EVALUASI RESPONS PERTUMBUHAN DAN NILAI HERITABILITAS IKAN NILA MERAH F-2 HASIL SELEKSI FAMILI PADA TAMBAK BERSALINITAS TINGGI
}

\author{
Adam Robisalmi ${ }^{\#}$, Priadi Setyawan, dan Bambang Gunadi \\ Balai Penelitian Pemuliaan Ikan
}

(Naskah diterima: 20 April 2015; Revisi final: 29 Juli 2015, Disetujui publikasi: 2 September 2015)

\begin{abstract}
ABSTRAK
Dalam rangka peningkatan produksi ikan nila, maka dilakukan kegiatan pembentukan ikan nila toleran salinitas tinggi strain nila merah yang tumbuh cepat di perairan payau. Kegiatan perbaikan genetik pada ikan nila merah ini dilakukan melalui jalur seleksi famili. Penelitian ini bertujuan untuk mengevaluasi pertumbuhan bobot dan mengetahui heritabilitas nyata ikan nila merah F-2 di tambak. Pembenihan dilakukan di air tawar menggunakan metode pemijahan secara fullsib dengan perbandingan induk jantan dan betina 1:1. Jumlah famili yang dipelihara sampai pembesaran di tambak adalah 16 famili. Sebelum penebaran di tambak, benih ikan nila merah diaklimatisasi dengan air laut sebanyak 5 salinitas 25 ppt. Kegiatan uji respons seleksi dilakukan di tambak bersalinitas 25-45 ppt selama tiga bulan. Selama pembesaran populasi jantan dan betina dipelihara secara terpisah. Parameter yang diamati adalah: pertumbuhan, nilai heritabilitas nyata, dan respons seleksi. Hasil penelitian menunjukkan bahwa populasi F-2 ikan nila merah seleksi mempunyai pertumbuhan yang lebih tinggi dibanding populasi F-2 kontrol. Nilai pertumbuhan bobot mutlak populasi jantan sebesar $100,37 \pm 7,43 \mathrm{~g}$ dengan laju pertumbuhan spesifik 1,44\% bobot/hari dan pertumbuhan bobot mutlak populasi betina $80,85 \pm 3,62 \mathrm{~g}$ dengan pertumbuhan spesifik 1,5\% bobot/hari. Nilai selisih bobot seleksi dengan kontrol pada populasi jantan 19,23 g dan betina 17,57 g. Nilai heritabilitas nyata yang diperoleh populasi F-2 ikan nila merah jantan dan betina sebesar 0,34 dan 0,41 dengan respons seleksi $18,10 \%$ dan $21,70 \%$.
\end{abstract}

KATA KUNCI: $\quad$ evaluasi, ikan nila merah F-2, seleksi, salinitas

ABSTRACT: Evaluation of growth response and heritability of red tilapia F-2 result of family selection at brackish water pond with high salinity. By: Adam Robisalmi, Priadi Setyawan, and Bambang Gunadi

In order to increase the production of tilapia, the formation of high salinity tolerant of red tilapia strains were grown in brackish water pond. Genetic improvement activities on red tilapia fish was done through family selection. This study aimed to evaluate the growth rate and calculate the real heritability of red tilapia reared in brackish water pond. Breeding was done in freshwater pond with fullsib mating design with male and female ratio of 1:1. The number of families that were kept up to enlargement in the pond was 16 families. Prior to stocking in ponds, red tilapia was acclimated by increasing salinity value of 5 ppt/day up to 25 ppt. Selection response test activities was carried out in the pond at salinity of 25-45 ppt for three months. During the enlargement of the male and female populations maintained separately. Parameters measured were growth, real heritability, and response selection. The results showed that selected F-2 grow faster than control. The absolute growth rate of male was $100.37 \pm 7.43$ while specific growth rate $1.44 \%$ weight/day and absolute growth rate of female $80.85 \pm 3.62 \mathrm{~g}$ while specific growth rate $1.5 \%$ weight/day. The difference weight value of selection and control on the male population $19.23 \mathrm{~g}$ and female $17.57 \mathrm{~g}$. Real heritability values obtained F-2 populations of red tilapia males and females 0.34 and 0.41 with response to selection $18.10 \%$ and $21.70 \%$.

KEYWORDS: $\quad$ evaluation, red tilapia F-2, selection, salinity

\# Korespondensi: Balai Penelitian Pemuliaan Ikan.

Jl. Raya Sukamandi No. 2, Subang 41256, Indonesia.

Tel.: + (0260) 520500

E-mail: aa_salmi@yahoo.com 


\section{PENDAHULUAN}

Ikan nila merupakan salah satu komoditas yang telah lama dibudidayakan karena bernilai ekonomis. Tingginya permintaan pasar terhadap ikan nila telah menyebabkan usaha budidaya ikan ini semakin banyak. Hal ini pula yang mendorong munculnya beberapa program pemuliaan yang dirancang untuk meningkatkan produksi ikan nila. Selama ini program pemuliaan dan kegiatan budidaya ikan nila terkonsentrasi di perairan tawar. Padahal banyak lahan-lahan yang di daerah pesisir dan perairan payau yang bisa dimanfaatkan untuk kegiatan pengembangan ikan nila, karena ikan nila dikenal mempunyai toleransi yang luas terhadap salinitas sehingga berpotensi untuk dibudidayakan di perairan payau dan laut. Salah satu strain ikan nila dengan keunggulan tersebut adalah nila merah. Ikan ini merupakan hasil persilangan Oreochromis niloticus x O. mossambicus (Pillay, 1991). Menurut Watanabe et al. (1988); El Sayed (2006), diketahui hibrid nila merah mempunyai pertumbuhan yang lebih baik di air laut yaitu pada salinitas $36 \mathrm{ppt}$ dan air payau dibandingkan di air tawar. Ikan nila merah yang diintroduksi ke Indonesia selama ini belum banyak dibudidayakan di perairan payau. Selain itu, ada faktor pembatas yaitu ketebalan daging yang tipis sehingga produksinya tidak setinggi ikan nila hitam. Oleh karena itu, perlu dilakukan perbaikan secara genetik pada ikan nila merah.

Dalam rangka peningkatan produksi ikan nila, maka dilakukan kegiatan pembentukan ikan nila merah toleran salinitas tinggi yang tumbuh cepat di perairan payau. Kegiatan perbaikan genetik pada ikan nila merah ini melalui jalur seleksi famili. Hal ini dikarenakan ikan nila memiliki nilai heritabilitas rendah dengan metode seleksi massa (Tave \& Smitherman, 1980; Hulata et al., 1986). Sedangkan dengan seleksi famili menunjukkan ada peningkatan respons pertumbuhan yang baik pada ikan nila yang diuji coba di Afrika (Eknath et al., 1998). Tujuan utama dari setiap program penyeleksian melalui perkawinan adalah untuk meningkatkan mutu dari keturunan suatu populasi yang sangat ditentukan oleh gen ikan tersebut (Noor, 2004; Tave, 1995). Menurut Tayamen et al. (2002), peningkatan dapat dilakukan melalui peningkatan laju pertumbuhan dan sintasan ikan. Pada beberapa kasus, peningkatan produktivitas juga dilakukan melalui seleksi yang bergantung kepada ketahanan ikan terhadap berbagai faktor lingkungan yang kurang menguntungkan, seperti salinitas. Seleksi famili merupakan metode untuk menyeleksi berdasarkan rataan suatu famili (Warwick et al., 1995).

Perbaikan populasi untuk mendapatkan varietas baru akan berhasil bila dalam populasi tersebut terdapat keragaman genetik yang luas akibat adanya perbedaan genotipe antara ikan dalam populasi. Estimasi parameter genetik seperti heritabilitas dan korelasi genetik adalah parameter penting dalam program perbaikan genetik, karena digunakan sebagai dasar untuk seleksi. Baihaki (2000) menyatakan bahwa kemajuan genetik didasarkan kepada perubahan dalam rata-rata penampilan yang dicapai dalam suatu populasi dalam setiap siklus selesai. Pada tahun 2013 telah diperoleh nilai estimasi heritabilitas untuk ikan nila merah sub populasi jantan sebesar 0,43 dengan prediksi peningkatan pertumbuhan bobot sebesar $11,10 \%$ dan sub-populasi betina sebesar 0,34 dengan peningkatan $8,14 \%$. Penelitian ini bertujuan untuk mengevaluasi peningkatan genetik ikan nila merah F-2 hasil seleksi famili. Selain itu, penelitian ini juga untuk memverifikasi nilai duga heritabilitas karakter bobot ikan nila merah F-1 hasil penelitian sebelumnya melalui penghitungan heritabilitas dalam arti nyata.

\section{BAHAN DAN METODE}

Kegiatan ini dilakukan di Balai Penelitian Pemuliaan Ikan, Sukamandi dan tambak di Kecamatan Losari Kabupaten Brebes pada April-November 2014. Pembentukan populasi F-2 ikan nila merah seleksi dilakukan dengan menggunakan induk-induk terseleksi F-1 sedangkan populasi kontrol F-2 menggunakan induk-induk F-1 non-seleksi, induk-induk ini didapatkan dari hasil penelitian tahun 2013. Metode pemijahan yang digunakan adalah full-sib mating design.

\section{Pembenihan}

Dalam kegiatan ini dilakukan pemijahan dengan perbandingan 1:1 pada induk-induk populasi terseleksi F-1 dan sebagai pembanding dipijahkan pula induk dari populasi kontrol. Pemijahan berlangsung 15 hari, famili yang memijah dalam waktu yang sama dalam kurun waktu lima hari dimasukkan dalam satu cohort. Hasil pemijahan 90 pasang induk terbentuk sebanyak 16 famili yang dapat dilanjutkan untuk pemeliharaan. Kegiatan pembenihan dilakukan di hapa berukuran $1 \mathrm{~m} \mathrm{x} 1 \mathrm{~m}$ per famili yang ditempatkan pada kolam $25 \mathrm{~m}^{2}$. Selanjutnya dilakukan koleksi larva, larva-larva yang terkoleksi dari masing-masing famili dipelihara dalam hapa pendederan ukuran $2 \mathrm{mx}$ $2 \mathrm{~m} \times 1 \mathrm{~m}$ selama 60 hari dengan padat tebar 125 ekor $/ \mathrm{m}^{2}$. Selama pendederan larva diberi pakan komersial 30\%-40\% dengan frekuensi tiga kali sehari secara ad libitum.

\section{Pembesaran}

Setelah benih mencapai ukuran $\pm 5 \mathrm{~cm}$, dilanjutkan dengan pembesaran di tambak bersalinitas 25 ppt dengan wadah waring-waring berukuran $5 \mathrm{~m} \mathrm{x}$ 2,5 $\mathrm{m} \times 1 \mathrm{~m}$, di mana sebelumnya benih diaklimati- 
sasi dengan air laut sebesar 5 ppt/hari. Setelah ikan mencapai ukuran 20-30 g/ekor, dilakukan seleksi berdasarkan jenis kelamin antara jantan dan betina. Kegiatan pembesaran dilakukan sampai ikan mencapai ukuran calon induk (100-200 g/ekor). Pemberian pakan dilakukan tiga kali sehari (pagi, siang, dan sore hari) sebanyak 5\%-10\%/biomassa menurun setiap bulan. Pakan yang diberikan memiliki kandungan protein $\pm 28 \%$.

\section{Seleksi}

Pada akhir pemeliharaan dilakukan proses seleksi pada karakter pertumbuhan (Gambar 1). Proses seleksi dibedakan antara jantan dan betina, karena ikan nila jantan dan betina memiliki tingkat pertumbuhan yang berbeda. Dari setiap famili, diambil sampel secara acak sebanyak 30 ekor individu kemudian dilakukan pengukuran terhadap bobot sehingga diperoleh data distribusi ukuran yang selanjutnya disortir (diurutkan) dari nilai terkecil hingga terbesar. Berdasarkan data distribusi ukuran yang telah disortir, ditetapkan batas minimum ukuran ikan yang akan diseleksi, yaitu 10\% individu jantan dengan keragaan fenotipe terbaik dari populasi. Prosedur yang sama diterapkan untuk memilih calon induk pada individu betina. Berdasarkan ukuran batas minimum yang telah diperoleh, dilakukan seleksi terhadap seluruh populasi. Calon induk jantan dipilih berdasarkan kriteria ukuran jantan sedangkan calon induk betina dipilih berdasarkan kriteria ukuran betina.

\section{Parameter}

Parameter yang diamati yaitu pertumbuhan meliputi: pertambahan bobot, laju pertumbuhan, dan sintasan, sedangkan parameter genetik meliputi: nilai koefisien keragaman bobot, diferensial seleksi, nilai heritabilitas, dan respons seleksi berdasarkan komponen keragaman. Kegiatan sampling dilakukan setiap satu bulan sekali dengan jumlah sampel yang diamati sebanyak 10\% dari jumlah ikan. Berikut adalah beberapa rumus yang digunakan:

Laju pertumbuhan spesifik (SGR), dihitung berdasarkan formula sebagai berikut:

$$
\mathrm{SGR}=\frac{(\ln \mathrm{Wt}-\ln \mathrm{Wo})}{\mathrm{t}} \times 100 \%
$$

di mana:

SGR $=$ Laju pertumbuhan spesifik (\%)

Wo $=$ Bobot awal

$\mathrm{Wt}=$ Bobot pada waktu $\mathrm{t}$

$\mathrm{t} \quad=$ Waktu pemeliharaan

Koefisien keragaman (CV) dihitung dengan menggunakan rumus Singh \& Chaudary (1977):

$$
\mathrm{KK}(\mathrm{CV})=\frac{\mathrm{SD}}{\mathrm{x}} \times 100 \%
$$

di mana:

$$
\mathrm{SD}=\text { Standar deviasi }(\%)
$$

$\mathrm{x}=$ Rataan populasi

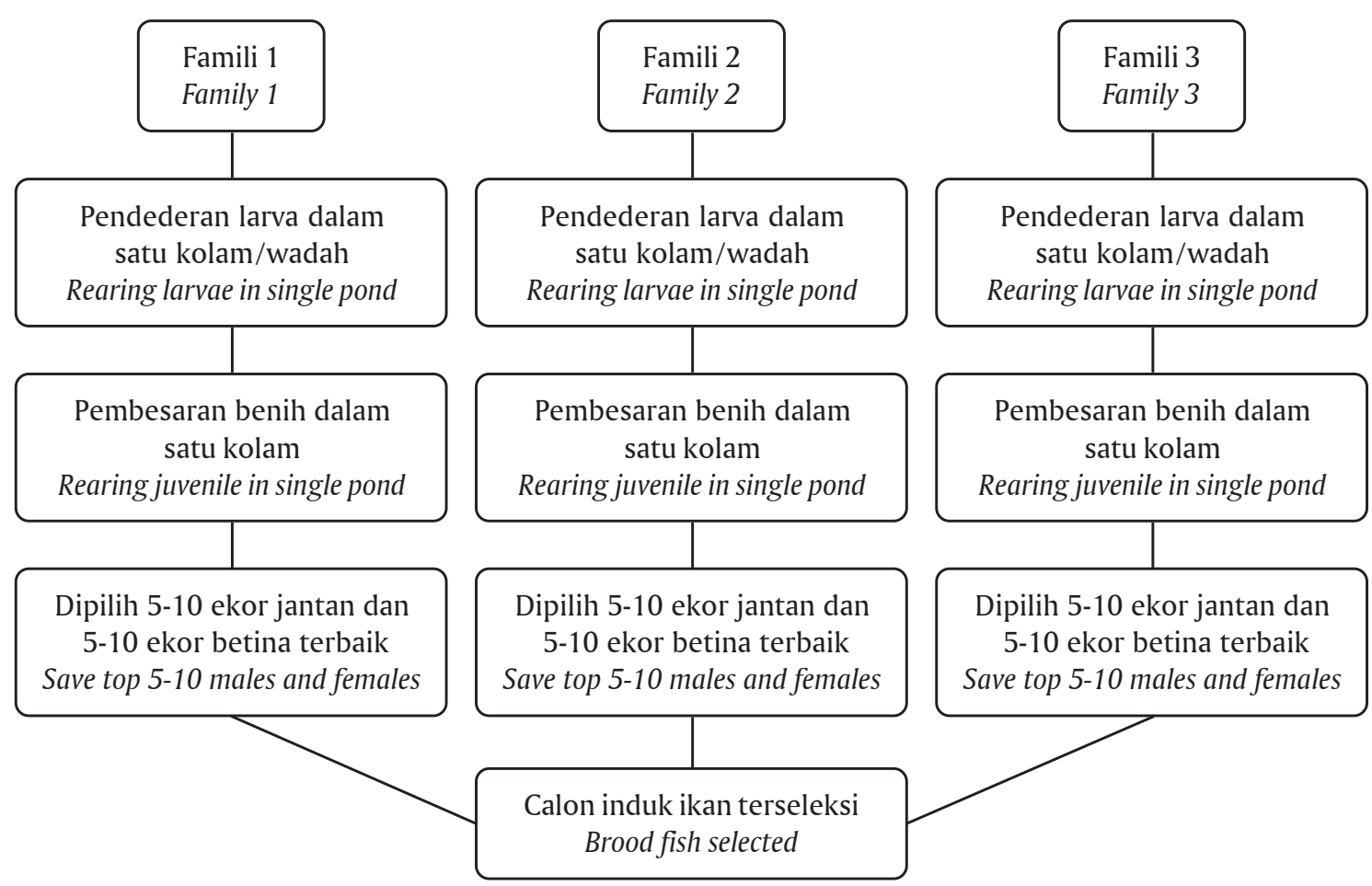

Gambar 1. Diagram alir seleksi famili ikan nila merah

Figure 1. Flow chart family selection of red tilapia 
Nilai diferensial seleksi (S), dihitung berdasarkan bobot rata-rata populasi dan bobot rata-rata populasi terseleksi. Nilai diferensial seleksi dihitung berdasarkan formula Singh \& Chaudary (1977) sebagai berikut:

$$
S=x^{\prime}-x
$$

di mana:

$S=$ Diferensial seleksi

$\mathrm{x}^{\prime}=$ Rata-rata bobot populasi terseleksi

$\mathrm{x}=$ Rata-rata bobot populasi

Respons seleksi (R), dihitung berdasarkan nilai selisih rata-rata populasi keturunan induk terseleksi dengan rata-rata populasi induk kontrol.

$$
\mathrm{R}=\mathrm{x}(\mathrm{F} 1)^{\prime}-\mathrm{x}(\mathrm{F} 0)
$$

di mana:

$\mathrm{R}=$ Respons seleksi

$\mathrm{x}(\mathrm{F} 1)=$ Bobot rata-rata terseleksi

$\mathrm{x}(\mathrm{F} 0)=$ Bobot rata-rata non-seleksi

Nilai heritabilitas nyata dihitung dengan formula:

$$
\mathrm{h}^{2}=\mathrm{R} / \mathrm{S}
$$

Falconer (1981)

di mana:

$\mathrm{h}^{2}=$ Heritabilitas

$\mathrm{S}=$ Diferensial seleksi

$\mathrm{R}=$ Respons seleksi

\section{Analisis Data}

Data-data yang diperoleh dianalisis metode Analysis of variance (ANOVA) menggunakan program SPSS.17.

\section{HASIL DAN BAHASAN}

\section{Pertumbuhan}

Berdasarkan Gambar 2 diketahui pola pertumbuhan bobot populasi ikan nila merah F-2 seleksi dan kontrol sub-populasi jantan dan betina. Ikan nila merah seleksi baik jantan dan betina terlihat setiap bulannya mempunyai bobot yang lebih baik dibanding populasi kontrol. Hal ini menunjukkan adanya peningkatan performa pada populasi F-2 dibanding generasi sebelumnya dikarenakan populasi kontrol merupakan gambaran dari populasi generasi F-1. Perbaikan performa ini merupakan hasil dari perbaikan secara genetik dari induk terseleksi F-1 walaupun faktor lingkungan tetap memberikan pengaruh yang cukup besar yaitu salinitas. Pada dasarnya ikan nila merah dapat tumbuh dan hidup di perairan payau walaupun sering terjadi fluktuasi salinitas yang tinggi. Sebagaimana dilaporkan Hulata (1995); Romana \& Eguia (1999); Watanabe et al. (2006) ikan nila merah red Florida maupun nila merah hibrid mempunyai performa pertumbuhan yang lebih baik dan toleransi yang tinggi pada perairan laut. Hal ini ditunjukkan dengan pertumbuhan yang cepat dan efisiensi pakan yang lebih baik.

Selama pemeliharaan terjadi fluktuasi salinitas yang tinggi yang berkisar 25-45 ppt, hal ini menyebabkan ikan mengalami penurunan nafsu makan dan berimplikasi terhadap pertumbuhan. Performa ikan nila merah F-2 mengalami penurunan dibanding dengan populasi ikan nila merah F-1 dikarenakan salinitas mencapai level di atas 45 ppt. Hasil penelitian Robisalmi \& Setyawan (2013) melaporkan bahwa pertumbuhan ikan nila merah F-1 seleksi selama tiga bulan pemeliharaan di tambak bersalinitas $25-40 \mathrm{ppt}$ menghasilkan pertambahan mutlak lebih tinggi sebesar $173,74 \mathrm{~g}$ sedangkan ikan nila merah F-2 100,37 g. Hasil penelitian Thouard et al. (1990) melaporkan bahwa ikan nila merah Florida yang dipelihara dari ukuran benih pada keramba jaring apung di laut mempunyai bobot lebih dari $350 \mathrm{~g}$ dalam kurun waktu enam bulan. Perbedaan ini mengindikasikan bahwa faktor lingkungan yaitu salinitas sangat memengaruhi pertumbuhan. Semakin tinggi salinitas maka aktivitas osmoregulasi ikan juga meningkat dan akan menyebabkan ikan melakukan homeostatis untuk mempertahankan diri terhadap lingkungan. Menurut Falconer (1981), menyatakan bahwa variasi genetik dan variasi lingkungan bersama-sama membentuk variasi fenotipe yang menyebabkan adanya perbedaan penampilan individu. Pada salinitas tinggi di atas 25 ppt ikan nila melakukan aktivitas homeostatis dengan melakukan respons fisiologis berupa aktivitas insang yang meningkat secara signifikan dan akan berbanding lurus dengan meningkatnya aktivitas osmoregulasi ion-ion $\mathrm{Na}^{+}, \mathrm{K}^{+}$, dan ATP-ase (Boyd, 1990; Guner et al., 2005). Ditambahkan Gilles (1987) menyatakan bahwa pertumbuhan ikan dapat dipengaruhi oleh beberapa faktor, yaitu: makanan, ruang, suhu, salinitas, musim, dan aktivitas fisik. Selain itu, umur dan ukuran ikan juga dapat berpengaruh pada toleransi salinitas ikan nila, di mana ukuran ikan lebih berpengaruh terhadap salinitas dibanding umur ikan (Villegas, 1990).

Pengujian respons pertumbuhan pada ikan nila merah F-2 dilakukan untuk mengevaluasi performa ikan nila hasil seleksi dibandingkan kontrol. Berdasarkan hasil uji statistik menunjukkan bahwa pertumbuhan mutlak dan pertumbuhan harian antara populasi seleksi dengan kontrol pada ikan nila merah F-2 jantan berbeda nyata $(\mathrm{P}<0,05)$ sedangkan nilai laju pertumbuhan spesifik tidak berbeda nyata $(P>0,05)$. Adapun pada populasi betina semua parameter pertumbuhan menunjukkan hasil berbeda 

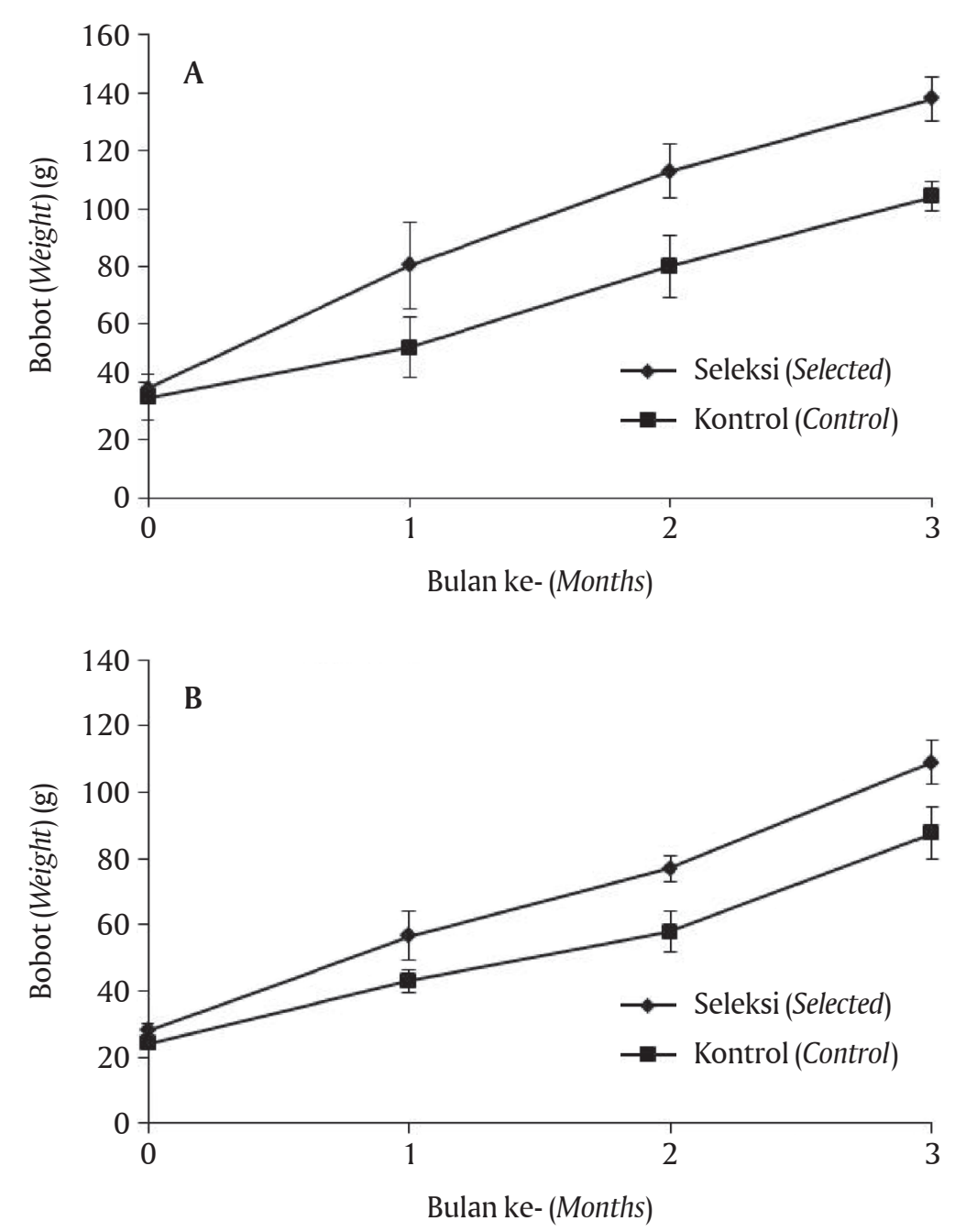

Gambar 2. Pola pertumbuhan ikan nila merah jantan (A) dan betina (B) populasi F-2 seleksi dan F-2 kontrol dipelihara dalam tambak selama tiga bulan pemeliharaan

Figure 2. Growth pattern of male (A) and female (B) red tilapia selected and control populations F-2 reared in brackish water pond for three months

nyata $(\mathrm{P}<0,05)$. Ikan nila merah sub populasi jantan seleksi setelah pemeliharaan selama 150 hari diketahui mempunyai nilai pertumbuhan mutlak karakter bobot mencapai 100,37 g dengan laju pertumbuhan spesifik $1,44 \%$ bobot/hari dan ikan nila merah sub populasi betina sebesar $80,85 \mathrm{~g}$ dengan pertumbuhan spesifik 1,5\% bobot/hari (Tabel 1). Perbedaan nilai bobot antara ikan nila seleksi dan kontrol telah terjadi ketika fase pendederan, sehingga pada saat awal penebaran di tambak untuk pembesaran bobot awalnya berbeda yang berimplikasi pada besarnya nilai bobot pada populasi seleksi di akhir pemeliharaan di tambak. Nilai yang lebih tinggi pada populasi seleksi dibandingkan dengan populasi kontrol mengindikasikan bahwa program seleksi berlangsung baik karena memiliki hasil yang positif sejak fase pendederan sampai pembesaran. Menurut Tave (1993), menyatakan rendahnya laju pertumbuhan pada suatu populasi ikan disebabkan oleh depresi inbreeding.
Selain itu, depresi inbreeding juga dapat mengakibatkan abnormalitas dan asimetrisme tinggi, kematangan kelamin dini, dan menurunkan fitness. Robisalmi \& Setyawan (2013) melaporkan bahwa ikan nila merah jantan dan betina pada pembesaran di tambak bersalinitas 20-30 ppt menghasilkan laju pertumbuhan spesifik masing-masing sebesar $2,03 \%$ bobot/hari dan $2,29 \%$ bobot/hari.

Selama pemeliharaan tiga bulan terjadi kematian pada ikan nila merah baik populasi seleksi maupun kontrol. Kematian terjadi lebih banyak ketika salinitas perairan tambak naik pada level 40 ppt. Pada ikan nila merah sub-populasi jantan seleksi dan kontrol masing-masing mempunyai nilai sintasan sebesar $70 \%$ dan $60 \%$, sedangkan ikan nila merah betina seleksi dan kontrol sebesar $87 \%$ dan $80 \%$ (Gambar 3). Nilai ini sedikit berbeda dengan laporan Robisalmi \& Setyawan (2013) bahwa sintasan populasi ikan nila merah jantan hasil pembesaran di tambak bersalinitas 25-30 
Tabel 1. Rerata pertumbuhan ikan nila merah jantan dan betina populasi terseleksi dan kontrol Table 1. Average growth of male and female red tilapia for selected and control populations

\begin{tabular}{|c|c|c|c|c|}
\hline \multirow{2}{*}{$\begin{array}{l}\text { Parameter } \\
\text { Parameters }\end{array}$} & \multicolumn{2}{|c|}{ Jantan (Male) } & \multicolumn{2}{|c|}{ Betina (Female) } \\
\hline & $\begin{array}{l}\text { Seleksi } \\
\text { Selected }\end{array}$ & $\begin{array}{l}\text { Kontrol } \\
\text { Control }\end{array}$ & $\begin{array}{l}\text { Seleksi } \\
\text { Selected }\end{array}$ & $\begin{array}{l}\text { Kontrol } \\
\text { Control }\end{array}$ \\
\hline Bobot awal (Initial weight) (g) & $37.67 \pm 4.97$ & $34.65 \pm 7.85$ & $28.16 \pm 2.26$ & $24.14 \pm 1.92$ \\
\hline Bobot akhir (Final weight) (g) & $138.04 \pm 7.60^{\mathrm{a}}$ & $104.22 \pm 5.28^{b}$ & $109.00 \pm 6.67^{\mathrm{a}}$ & $87.60 \pm 7.9^{b}$ \\
\hline Pertumbuhan mutlak (Absolute growth) (g) & $100.37 \pm 7.43^{\mathrm{a}}$ & $69.57 \pm 8.08^{\mathrm{b}}$ & $80.85 \pm 3.62^{\mathrm{a}}$ & $63.46 \pm 4.37^{\mathrm{b}}$ \\
\hline $\begin{array}{l}\text { Laju pertumbuhan spesifik (\% bobot/hari) } \\
\text { Specific growth rate (\% weight/day) }\end{array}$ & $1.44 \pm 0.05^{\mathrm{a}}$ & $1.22 \pm 0.09^{\mathrm{a}}$ & $1.50 \pm 0.05^{\mathrm{a}}$ & $1.43 \pm 0.06^{b}$ \\
\hline $\begin{array}{l}\text { Laju pertumbuhan harian (g/hari) } \\
\text { Daily growth rate (g/day) }\end{array}$ & $1.12 \pm 0.08^{\mathrm{a}}$ & $0.77 \pm 0.11^{b}$ & $0.89 \pm 0.04^{\mathrm{a}}$ & $0.71 \pm 0.05^{\mathrm{b}}$ \\
\hline
\end{tabular}

Keterangan (Note):

Nilai dengan keterangan huruf yang sama menunjukkan hasil berbeda nyata $(\mathrm{P}<0,05)($ Value with same alphabet means significant different $(P<0.05))$

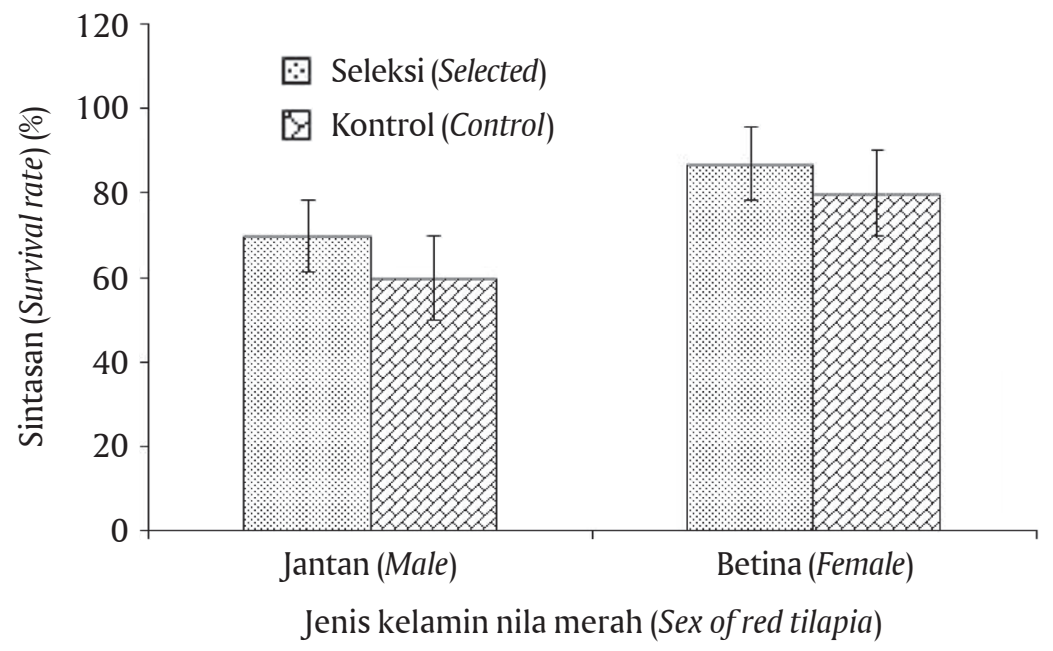

Gambar 3. Sintasan ikan nila merah selama tiga bulan pemeliharaan

Figure 3. Survival of red tilapia for three months of culture

berkisar $80 \%-90 \%$ sedangkan ikan nila merah betina 70\%-80\%. Apabila dibandingkan antara ikan nila seleksi maupun kontrol tidak terlihat perbedaan yang tinggi, perbedaan justru terlihat apabila dibandingkan antara populasi jantan dan betina, di mana ikan nila merah betina mempunyai sintasan yang lebih tinggi dibanding jantan. Kematian lebih banyak pada ikan yang berukuran lebih besar yaitu populasi jantan ketika salinitas meningkat, hal ini terjadi nafsu makan berkurang sedangkan energi yang digunakan untuk proses osmoregulasi dan metabolisme meningkat sehingga ikan mengalami stress sampai mati. Fenomena ini kontras dengan pernyataan Watanabe et al. (1985); Prunet \& Bornancin (1989) semakin besar ukuran ikan maka kemampuan osmoregulasinya semakin toleran terhadap kenaikan salinitas dibandingkan dengan ikan yang berukuran kecil. Perubahan salinitas di perairan akan berimplika- si langsung terhadap sintasan, pertumbuhan, metabolisme, dan distribusi ikan karena memengaruhi tekanan osmotik dan konsentrasi ion cairan tubuh (Kinne, 1964; Holiday, 1969).

Pada Tabel 2 diketahui data distribusi bobot badan ikan nila merah F-2 dalam satu famili menyebar dari nilai rata-ratanya. Nilai koefisien keragaman (KK) berguna untuk memberikan gambaran seberapa besar keragaman dalam suatu populasi akan mendukung keberhasilan suatu program seleksi. Pada sub-populasi jantan, nilai KK menyebar dari kisaran 14,12\%$39,66 \%$ nilai ini lebih tinggi dibanding sub-populasi betina yaitu $11,10 \%-33,13 \%$. Berdasarkan hasil yang ada maka bisa disebutkan bahwa koefisien keragaman bobot ikan nila merah F-2 termasuk dalam kategori rendah dan sedang, hal ini disebabkan karena adanya keragaman genetik dan lingkungan. Menurut 
Tabel 2. Nilai koefisien keragaman karakter bobot pada populasi jantan dan betina ikan nila merah F-2

Table 2. The coefficient of variance in weight of the male and female population of red tilapia F-2

\begin{tabular}{ccc}
\hline \multirow{2}{*}{$\begin{array}{c}\text { Kode } \\
\text { Code }\end{array}$} & \multicolumn{2}{c}{$\begin{array}{c}\text { Koefisien keragaman (CV) \% bobot badan } \\
\text { Coefficient of variance (CV) of weight }\end{array}$} \\
\cline { 2 - 3 } & Jantan (Male) & Betina (Female) \\
\hline F-1 & 30.89 & 22.26 \\
F-2 & 29.37 & 17.70 \\
F-3 & 26.70 & 16.23 \\
F-5 & 29.19 & 33.13 \\
F-6 & 19.98 & 18.48 \\
F-7 & 29.85 & 24.87 \\
F-8 & 30.84 & 29.29 \\
F-10 & 24.06 & 19.10 \\
F-11 & 25.92 & 19.58 \\
F-12 & 27.02 & 26.87 \\
F-13 & 15.85 & 11.10 \\
F-14 & 39.66 & 23.36 \\
F-15 & 18.98 & 29.98 \\
F-16 & 28.41 & 18.66 \\
F-17 & 14.12 & 21.34 \\
F-19 & 29.75 & - \\
\hline
\end{tabular}

Tave (1993), semakin tinggi nilai koefisien keragaman dalam suatu populasi maka hal itu semakin menunjukkan keberagaman ukuran individu dalam populasi tersebut. Untuk keberhasilan program pemuliaan sangat ditentukan oleh tersedianya ragam genetik. Semakin tinggi keragaman genetik yang dimiliki akan semakin besar peluang keberhasilan bagi program pemuliaan. Di samping itu, keragaman yang tinggi juga dapat meningkatkan respons seleksi karena respons seleksi berbanding lurus dengan keragaman genetik (Hallauer \& Miranda, 1988).

\section{Seleksi}

Berdasarkan data bobot rata-rata pada populasi ikan nila merah F-2 dari masing-masing famili dilakukan cut-off untuk melakukan seleksi terhadap individu-individu dalam famili, hal ini dilakukan karena metode seleksi yang digunakan adalah seleksi dalam famili (within family). Adapun batas minimum ukuran ikan yang akan diseleksi, yaitu $10 \%$ baik pada populasi jantan dan betina dari tiap-tiap famili yang memiliki keragaan fenotipe (bobot) terbaik dari populasi. Nilai cut-off famili-famili pada populasi jantan berkisar antara 248-364 g, nilai ini lebih tinggi dibanding nilai cut-off famili-famili pada populasi betina yang berkisar dari 218-248 g. Sedangkan nilai di- ferensial seleksi diperoleh dari selisih antara bobot rata-rata terseleksi dengan bobot rata-rata populasi F-1, yang mana nilai diferensial seleksi populasi jantan lebih tinggi dibanding betina. Dengan tingginya nilai diferensial seleksi maka akan berimplikasi terhadap respons seleksi. Sehingga apabila nilai diferensial seleksi dari populasi yang akan kita seleksi besar maka peluang terjadi peningkatan genetik pada generasi selanjutnya juga tinggi. Selaras dengan Kirpichnikov (1981) bahwa peningkatan diferensial seleksi dapat dilakukan melalui peningkatan variasi komponen genetik (additive) atau peningkatan proporsi antara variasi genetik dan fenotipe secara bersamaan. Nilai bobot rata-rata populasi, bobot ratarata terseleksi, dan diferensial seleksi populasi jantan dan betina ikan nila merah F-1 disajikan pada Tabel 3a dan 3b.

\section{Peningkatan Fenotipe Bobot dan Heritabilitas}

Salah satu indikator ada tidaknya perbaikan genetik adalah dengan melihat penampilan fenotifik suatu karakter yang menjadi dasar untuk dilakukan seleksi dalam hal ini bobot badan. Menurut Tave (1993), fenotipe adalah setiap karakteristik yang dapat diukur yang dipunyai organisme dan merupakan hasil interaksi antara genotipe dan lingkungan, serta merupakan sifat yang tampak. Pada Tabel 3 ditunjukkan nilai perbaikan genetik yang merupakan hasil dari selisih rataan bobot populasi terseleksi F-2 dengan populasi kontrol pada akhir pemeliharaan.

Berdasarkan Tabel 4 diketahui selisih bobot populasi ikan nila merah F-2 sub-populasi jantan dengan kontrol sebesar 19,23 g dan pada sub-populasi betina sebesar 17,57 g. Hal ini mengindikasikan adanya peningkatan pertumbuhan karakter bobot ikan nila merah F-2 sebesar 18,10\% (jantan) dan 21,74\% (betina) dari populasi F-2 kontrol dipengaruhi faktor genetik. Nilai heritabilitas pada penelitian ini merupakan nilai heritabilitas nyata yang diperoleh dari hasil perhitungan antara perbandingan respons seleksi (selisih bobot F-2 seleksi ikan nila merah dengan bobot F-2 kontrol) dengan nilai diferensial seleksi pada populasi F-1.

Nilai heritabilitas ikan nila merah sub-populasi jantan diperoleh sebesar 0,34 dan ikan nila merah betina sebesar 0,41 . Rendahnya nilai heritabilitas pada ikan nila jantan dibanding ikan betina disebabkan karena tingginya diferensial seleksi bobot jantan. Menurut Noor (2004), diferensial seleksi dapat lebih besar pada kelompok populasi yang besar, sebab pada populasi yang besar akan semakin besar pula kemungkinan dijumpainya individu yang performanya di atas atau di bawah rataan. Hasil ini lebih baik dibanding penelitian Robisalmi \& Dewi (2014) bahwa 
Tabel 3a. Nilai bobot rerata populasi, cut off, bobot rerata terseleksi, dan diferensial seleksi dari setiap famili ikan nila merah F-2 sub-populasi jantan selama tiga bulan

Table 3a. The individual weight of the population cut-off values, selected individual weight, and the selection differential female population of male red tilapia for three months period

\begin{tabular}{lcccc}
\hline $\begin{array}{c}\text { Kode } \\
\text { Code }\end{array}$ & $\begin{array}{c}\text { Bobot rerata populasi } \\
\text { Individual weight of population }\end{array}$ (g) & $\begin{array}{c}\text { Cut off } \\
\text { (g) }\end{array}$ & $\begin{array}{c}\text { Bobot rerata terseleksi } \\
\text { Selected individual weight }(\mathbf{g})\end{array}$ & $\begin{array}{c}\text { Diferensial seleksi } \\
\text { Selection differential }(\mathbf{g})\end{array}$ \\
\hline F-1 & $125.90 \pm 38.90$ & 164 & $172.67 \pm 19.20$ & 46.77 \\
F-2 & $163.31 \pm 47.96$ & 200 & $213.14 \pm 33.72$ & 49.83 \\
F-3 & $112.00 \pm 29.30$ & 142 & $152.60 \pm 18.16$ & 40.60 \\
F-5 & $140.47 \pm 41.01$ & 172 & $194.80 \pm 29.45$ & 54.33 \\
F-6 & $112.21 \pm 22.42$ & 130 & $136.80 \pm 10.52$ & 24.59 \\
F-7 & $91.53 \pm 27.32$ & 120 & $125.75 \pm 7.30$ & 32.87 \\
F-8 & $91.74 \pm 28.29$ & 115 & $127.20 \pm 14.18$ & 35.47 \\
F-10 & $135.68 \pm 32.64$ & 165 & $172.33 \pm 13.37$ & 36.65 \\
F-11 & $97.47 \pm 25.26$ & 126 & $131.00 \pm 7.62$ & 33.53 \\
F-12 & $108.55 \pm 29.33$ & 134 & $148.75 \pm 15.33$ & 40.19 \\
F-13 & $95.93 \pm 15.20$ & 102 & $112.20 \pm 13.79$ & 16.27 \\
F-14 & $116.50 \pm 46.20$ & 162 & $184.20 \pm 32.32$ & 67.70 \\
F-15 & $91.20 \pm 17.31$ & 108 & $112.75 \pm 5.81$ & 21.55 \\
F-16 & $109.00 \pm 30.97$ & 137 & $146.67 \pm 14.85$ & 37.67 \\
F-17 & $104.22 \pm 14.71$ & 110 & $130.00 \pm 11.31$ & 16.00 \\
F-19 & $124.85 \pm 37.15$ & 162 & $168.17 \pm 17.08$ & 29.75 \\
\hline
\end{tabular}

Tabel 3b. Nilai bobot rerata populasi, cut off, bobot rerata terseleksi, dan diferensial seleksi dari setiap famili ikan nila merah F-2 sub populasi betina selama tiga bulan

Table 3b. The individual weight of the population cut-off values, selected individual weight, and the selection differential female population of female red tilapia for three months period

\begin{tabular}{ccccc}
\hline $\begin{array}{c}\text { Kode } \\
\text { Code }\end{array}$ & $\begin{array}{c}\text { Bobot rerata populasi } \\
\text { Individual weight of population } \mathbf{( g )}\end{array}$ & $\begin{array}{c}\text { Cut off } \\
\mathbf{( g )}\end{array}$ & $\begin{array}{c}\text { Bobot rerata terseleksi } \\
\text { Selected individual weight } \mathbf{( g )}\end{array}$ & $\begin{array}{c}\text { Diferensial seleksi } \\
\text { Selection differential } \mathbf{( g )}\end{array}$ \\
\hline F-1 & $93.35 \pm 20.78$ & 107 & $114.75 \pm 8.99$ & 21.39 \\
F-2 & $134.38 \pm 24.64$ & 140 & $159.00 \pm 7.07$ & 19.75 \\
F-3 & $82.86 \pm 13.44$ & 95.8 & $99.25 \pm 6.55$ & 16.23 \\
F-5 & $105.69 \pm 35.01$ & 140 & $142.80 \pm 8.52$ & 37.11 \\
F-6 & $81.40 \pm 15.04$ & 84.8 & $93.25 \pm 22.62$ & 11.85 \\
F-7 & $90.64 \pm 22.54$ & 113 & $123.00 \pm 10.53$ & 32.36 \\
F-8 & $103.38 \pm 30.28$ & 131 & $140.25 \pm 3.53$ & 36.87 \\
F-10 & $99.00 \pm 18.90$ & 115.2 & $120.00 \pm 4.98$ & 21.00 \\
F-11 & $71.11 \pm 13.92$ & 78.8 & $91.00 \pm 7.07$ & 19.89 \\
F-12 & $71.63 \pm 19.24$ & 80 & $102.25 \pm 20.20$ & 30.62 \\
F-13 & $70.09 \pm 7.77$ & 77.6 & $81.00 \pm 4.99$ & 10.91 \\
F-14 & $78.75 \pm 18.39$ & 94.6 & $100.80 \pm 9.63$ & 22.05 \\
F-15 & $72.35 \pm 21.68$ & 94.2 & $101.60 \pm 15.66$ & 29.25 \\
F-16 & $75.07 \pm 14.07$ & 81 & $96.66 \pm 12.41$ & 20.60 \\
F-17 & $71.76 \pm 15.31$ & 100 & $102.00 \pm 13.97$ & 30.23 \\
\hline
\end{tabular}

estimasi nilai heritabilitas bobot ikan nila merah populasi jantan dan betina yang dipelihara selama lima bulan di tambak bersalinitas 25-30 ppt yaitu sebesar $0,47 \pm 0,19$ dan $0,19 \pm 0,11$ sedangkan ikan nila hitam yang dibesarkan di tambak bersalinitas $15-20 \mathrm{ppt}$ menghasilkan nilai heritabilitas sebesar 0,53 (Ninh et al., 2014). Adapun Charo-Karisa et al. (2006) menyatakan nilai rataan heritabilitas tersebut, relatif 
Tabel 4. Nilai rataan bobot populasi seleksi, kontrol, respons seleksi, diferensial seleksi, dan heritabilitas ikan nila merah F-2 hasil pemeliharaan di tambak selama tiga bulan

Table 4. Individual weight of selection population, control population, response to selection, selection differential, and heritability of red tilapia F-2 at brackish water pond for three months period

\begin{tabular}{|c|c|c|c|c|c|}
\hline \multirow[b]{2}{*}{ Sub-populasi } & \multicolumn{2}{|c|}{$\begin{array}{l}\text { Rataan bobot populasi } \mathrm{F}-2 \\
\text { Individual weight of } F-2 \text { population }\end{array}$} & \multirow{2}{*}{$\begin{array}{l}\text { Respons seleksi } \\
\text { Response to } \\
\text { selection (\%) }\end{array}$} & \multirow{2}{*}{$\begin{array}{c}\text { Diferensial seleksi } \\
\text { F-1 (Selection } \\
\text { differential F-1 ) }\end{array}$} & \multirow{2}{*}{$\begin{array}{c}\text { Heritabilitas } \\
\text { Heritability } \\
{\left(\mathbf{h}^{2}\right)}^{2}\end{array}$} \\
\hline & $\begin{array}{l}\text { Seleksi } \\
\text { Selected }\end{array}$ & $\begin{array}{l}\text { Kontrol } \\
\text { Control }\end{array}$ & & & \\
\hline Jantan (Male) & 106.25 & 87.02 & 18.1 & 57.08 & 0.34 \\
\hline Betina (Female) & 80.83 & 63.26 & 21.74 & 42.94 & 0.41 \\
\hline Rerata (Average) & 93.54 & 75.14 & 19.92 & 50.01 & \\
\hline
\end{tabular}

lebih kecil dibandingkan nilai heritabilitas bobot ikan nila umur 289-318 hari yang mencapai 0,38-0,60 dan 0,12-0,56 pada ikan nila GIFT generasi ketiga hasil pembesaran pada berbagai lingkungan budidaya (Eknath et al., 2007). Perbedaan nilai heritabilitas ini terjadi dikarenakan adanya ketidaksamaan sistem budidaya antara pembesaran di kolam air tawar dengan air payau, serta waktu pemeliharaan.

Besaran nilai heritabilitas ikan nila merah F-2 pada kisaran 0,34-0,41 termasuk dalam kategori sedang dan tinggi. Nilai ini menunjukkan bahwa faktor genetik dan lingkungan sama-sama berperan dalam menentukan karakter bobot. Menurut Noor (2004), nilai heritabilitas dapat digolongkan ke dalam tiga kategori yaitu: rendah, sedang, dan tinggi. Nilai heritabilitas rendah, jika nilainya berada antara $0-0,20$; sedang antara 0,2-0,4; dan tinggi untuk nilai lebih dari 0,4 sedangkan Falconer (1981) nilai $h^{2}$ karakter kuantitatif pada ikan terdiri atas tingkatan yaitu: rendah $(0-0,1)$, sedang $(0,1-0,3)$, dan tinggi $(0,3-1,0)$.

Nilai respons seleksi pada populasi F-2 yang mencapai $18,10 \%$ pada sub-populasi jantan dan $21,74 \%$ untuk sub-populasi betina menunjukkan keberhasilan seleksi dari generasi sebelumnya. Nilai ini lebih besar dari respons seleksi populasi ikan nila merah F-1 sebesar 15,99\%. Selaras dengan penelitian CharoKarisa et al. (2006) melaporkan bahwa respons seleksi pada ikan nila antara G-0 dan G-1 yaitu 23,4 g (34,7\%) sedangkan antara G-1 dan G-2 sebesar $13 \mathrm{~g}$ (14,9\%). Menurut Warwick et al. (1995); Ponzoni et al. (2005), memprediksi adanya kenaikan kemajuan genetik rata-rata sebesar $10 \%$ pada setiap generasi hasil kegiatan seleksi. Beberapa penelitian sebelumnya melaporkan bahwa persentase peningkatan genetik (genetic gain) pada ikan nila berkisar dari 10\%-13,3\% (Bolivar \& Newkirk (2002); Gall \& Bakar (2002); Hamzah et al. (in press); Ponzoni et al. (2005). Hal ini selaras dengan pernyataan Gjedrem (2000) bahwa peningkatan genetik yang dicapai dalam program pemuliaan di perairan payau sebesar $5 \%-20 \%$ seperti pada ikan yang lain.

Nilai heritabilitas dan respons seleksi yang tinggi pada ikan nila merah F-2 menunjukkan keberhasilan program seleksi. Kasno et al. (1989) menyatakan nilai heritabilitas tinggi yang diikuti oleh respons seleksi tinggi merupakan hasil kerja gen aditif. Sebaliknya suatu sifat yang memiliki nilai heritabilitas tinggi dan diikuti dengan respons seleksi rendah akibat pengaruh gen bukan aditif (dominan, epistasis). Kemajuan genetik harapan merupakan tolak ukur dalam persen dari pergeseran nilai tengah populasi dari kondisi populasi sampai kondisi setelah dilakukan seleksi, dengan asumsi besaran differensial.

\section{KESIMPULAN}

Pertumbuhan populasi ikan nila merah F-2 terseleksi sub populasi jantan dan betina lebih tinggi dibanding populasi F-2 kontrol.

Nilai heritabilitas nyata $\left(h^{2}\right)$ karakter bobot pada populasi ikan nila merah sub-populasi jantan dan betina termasuk dalam kategori sedang dan tinggi masing-masing sebesar 0,34 dan 0,41 dengan respons seleksi $18,10 \%$ dan $21,70 \%$.

\section{DAFTAR ACUAN}

Baihaki, A. (2000). Teknik rancangan dan analisis penelitian pemuliaan. Fakultas Pertanian. Universitas Padjajaran. Bandung, $91 \mathrm{hlm}$.

Boyd, C.E. (1990). Water quality in pond for aquaculture. Auburn University Press. Alabama, 482 pp.

Bolivar, R.B., \& Newkirk, G.F. (2002). Response to within family selection for body weight in Nile tilapia (Oreochromis niloticus) using a single-trait animal model. Aquaculture, 204, 371-381.

Charo-Karisa, H., Komen, H., Rezk, M.A., Ponzoni, R.W., van Arendonk, J.A.M., \& Bovenhius, H. (2006). Heritability estimates and response to 
selection for growth of nile tilapia (Oreochromis niloticus) in low-input earthen ponds. Aquaculture, 261, 479-486.

Eknath, A.E., Dey, M.M., Rye, M., Gjerde, B., Abella, T.A., Sevilleja, R., Tayamen, M.M., Reyes, R.A., \& Bentsen, H.B. (1998). Selective breeding of nile tilapia for Asia.

Eknath, A.E., Bentsen, H.B., Ponzoni, R.W., Rye, M., Nguyen, N.H., Thodesen J., \& Gjerde, B. (2007). Genetic improvement of farmed tilapias: composition and genetic parameters of a synthetic base population of Oreochromis niloticus for selective breeding. Aquaculture, 273, 1-14.

El Sayed, A.F.M. (2006). Tilapia culture in salt water: enviromental requirements, nutritional implications and economic potential. Simpocium International de nutricion auicola. Mexico, p. 95-106.

Falconer, D.S. (1981). Introduction to quantitative genetics. $2^{\text {nd }}$ edition. Longman, Inc. United Kingdom.

Gall, G.A.E. \& Bakar, Y. (2002). Application of mixedmodel techniques to fish breed improvement: analysis of breeding-value selection to increase 98-day body weight in tilapia. Aquaculture, 212, 93-113.

Gjedrem, T. (2000). Genetic improvement of coldwater fish species. Aquaculture Research, 31, 2533.

Gilles, R. (1987). Volume regulation in cells of euryhaline invertebrates. In Kleinzeller, A. (Ed.). Cell volume control: fundamental and comparative aspects in animal cells, vol. 30, p. 205-247. New York. Academic Press.

Guner, Y., Ozden, O., Cagirgan, H., Altunok, M., \& Kizak, V. (2005). Effects of salinity on the osmoregulatory functions of the gills in nile tilapia (Oreochromis niloticus). Turky J. Vet Animal Science, 29, 1259-1266.

Hallauer, A.R., \& Miranda, J.B. (1988). Quantitative genetics in maize breeding. Iowa State University Press. 468 pp.

Hulata, G. (2001). Genetic manipulations in aquaculture: a review of stock improvement by classical and modern technologies. Genetica, 111, 155-173.

Holiday, F.G.T. (1969). The effect of salinity on eggs and larvae of teleost. p. 293-309. In Hoar, W.S., \& Randall, D.J. (Eds.). Fish Physiology, 1. Acad. N.Y. and London.

Kasno, A., Basri, A., Matjik, A.A., Salahudin, S., Somaatmadja, S., \& Subandi. (1989). Telaah interaksi genotipe $\mathrm{x}$ lingkungan pada kacang tanah. Pendugaan parameter genetik hasil dan komponen hasil kacang tanah (Arachis hypogaea Merr.). Penelitian Palawija, 2(2), 81-88.
Kinne, O. (1964). The effect of temperature and salinity on marine and brackish water animals. p. 281-336. In Barnes, H. (Ed.). The Oceaonography and Marine Biology, II. George, A., \& Unwin Ltd. London.

Kirpchnikov, V.S. (1991). Genetics base of fish selection. Springer-Verlag. Berlin.

Ninh, A.H., Ngo, P.T., Wayne, K., \& Nguyen, H.N. (2014). Selection for enhanced growth performance of nile tilapia (Oreochromis niloticus) in brackish water (15-20 ppt) in Vietnam. Aquaculture, 428-429, 1-6.

Noor, R.R. (2004). Genetika ternak. Penebar Swadaya. Jakarta, $199 \mathrm{hlm}$.

Pillay, T.V.R. (1991). Tilapias. Aquaculture-Principles and Practices, 19, 360-376.

Ponzoni, R.W., Hamzah, A., Tan, S., \& Kamaruzzaman, N. (2005). Genetic parameters and response to selection for live weight in the GIFT strain of nile tilapia (Oreochromis niloticus). Aquaculture, 247, 203-210.

Prunet, P., \& Bornancin, M. (1989). Physiology of salinity tolerance in tilapia: an update of basic and applied aspects. Aquat. Living Resour., 2, 91-97.

Robisalmi, A., \& Dewi, R.R.S.P.S. (2014). Estimasi heritabilitas dan respons seleksi ikan nila merah (Oreochromis spp.) pada tambak bersalinitas. J. Ris. Akuakultur, 9(1), 47-57.

Robisalmi, A., \& Setyawan, P. (2014). Penampilan fenotipe populasi jantan dan betina ikan nila merah hasil seleksi famili di tambak. Laporan Teknis Penelitian 2013 BPPI Sukamandi.

Romana-Eguia, M.R.R., \& Eguia, R.V. (1999). Growth of five Asian red tilapia strains in saline environments. Aquaculture, 173(1-4), 161-170.

Singh, R.K., \& Chaudary, B.D. (1977). Biometrical methods in quantitative genetics analysis. Kalyani Publishers. Indiana. New Delhi, 304 pp.

Tave, D., \& Smitherman, R.O. (1980). Predicted response to selection for early growth in Tilapia nilotica. Trans. Am. Fish. Soc., 109, 439-445.

Tave, D. (1993). Genetic for fish hatchery managers. $2^{\text {nd }}$ ed. AVI. Publishing Company. Inc. Connecticut.

Tave, D. (1995). Selective breeding programmes for medium-sized fish farm. Roma.

Tayamen, M.M., Reyes, R.A., Danting, M.J., Mendoza, A.M., Marquez, E.B., Salguet, A.C., Gonzales, R.C., Abella, T.A., \& Vera-Cruz, E.M. (2002). Tilapia broodstock development for saline waters in the Philippines. NAGA-ICLARM Quarterly, 25(1), 32-36.

Thouard, E., Soletchnik, P., \& Marion, J.P. (1990). Selection of tintish species for aquaculture development in Martinique (F.W.I.). Aquaculture, 89, 193197. 
Villegas, C.T. (1990). Growth and survival of Oreochromis niloticus, 0 . mossambicus, and their F1 hybrids at various salinities. Proceedings of the Second Asian Fisheries Society. Manila. Philippines, p. 507-510.

Warwick, E.J., Astuti, J.M., \& Wardjosubroto, W. (1995). Pemuliaan ternak. Gadjah Mada University Press. Yogyakarta, $485 \mathrm{hlm}$.
Watanabe, W.O., Kuo, C.M., \& Huang, M.C. (1985). The ontogeny of salinity tolerance in the tilapias Oreochromis niloticus, 0 . aureus, and 0 . mossambicus $\mathrm{x} 0$. niloticus hybrid, spawned and hatched in freshwater. Aquaculture, 47, 353-367.

Watanabe, W.O., Fitzsimmons, K., \& Yi, Y. (2006). Farming tilapia in saline water. In Tilapia: Biology, culture and nutrition (Eds.). The Haworth Press, Inc. 